\title{
Isolation of L-forms by blood culture
}

\author{
OONAGH BROGAN
}

From the Department of Bacteriology, Victoria Infirmary, Glasgow

SYNOPSIS Culture media for the isolation of bacterial L-forms from the blood were studied. The most successful media had an osmolality of more than $1100 \mathrm{mosm} / \mathrm{kg}$ and this appeared to be $\mathrm{a}_{-}^{\circ}$ critical factor in determining success.

The L-forms of bacteria are bacteria which have been deprived of all or part of the cell wall. They cannot grow on ordinary culture media nor are they demonstrable by routine microscopy. They are filterable and can pass through 'sterilizing' filters. Though there is increasing interest in the L-forms of bacteria, there are few comparative studies of culture methods. Those that have been done are mainly concerned with the study of wall-defective microbial variants induced in vitro rather than with material derived from clinical specimens. The object of the work reported in this paper was to devise a suitable medium for the isolation of $\mathbf{L}$-forms from clinical material. Blood cultures were chosen for investigation because the results of this examination are seldom equivocal. The isolation of $\mathrm{L}$-forms from the blood has been reported, but this investigation is generally disappointing and the role of the bacterial L-form in disease remains to be elucidated.

\section{Material and methods}

\section{PRELIMINARY WORK}

Wall-defective microbial variants were artificially induced in $20 \%$ sucrose brain heart infusion broth containing ampicillin, using 10 doubling dilutions of ampicillin ranging from $1.9 \mu \mathrm{g}$ to $100 \mu \mathrm{g} / \mathrm{ml}$. The test organisms were the Oxford staphylococcus (NCTC No. 6571) and an Escherichia coli strain (NCTC No. 10418). Three media were tested using the artificially produced wall-defective bacteria. These were the L-form media of Gutman et al (1965), Difco PPLO broth (without CV), and the BYSP medium of Nimmo and Blazevic (1969). The effect of sodium polethanol sulphate (SPS) heparin and tetrazolium was also tested in these media. In order to ensure that wall-defective bacteria were being tested, cultures were filtered through a Millipore $0.22 \mu$ filter before the media were inoculated.

Received for publication 18 March 1976
ISOLATION FROM BLOOD CULTURES All blood cultures examined during a period of $2 \frac{1}{2}-$ years were cultured in a medium designed to recover:o L-form bacteria. Two media for routine culture were ${ }_{+}^{\omega}$ also inoculated from each specimen, and all media을 were inoculated at the bedside. There were seven testmedia, and these were designated A to $G$. Each was $\bigcirc$ allotted a minimum period of 12 weeks' trial and each $\stackrel{\circ}{\circ}$ test group contained at least 150 specimens. A totalס of 1527 specimens was examined in this way. Throughout this study incubation was at $37^{\circ} \mathrm{C}$. The $\vec{\theta}$ incubation atmosphere was aerobic for groups $\mathrm{A}, \mathbb{\$}$, , $C$, and $\mathbf{D}$ and anaerobic for groups $E, F$, and Anaerobiosis was maintained by the use of Gaspak system (BBL).

\section{MEDIA}

The test and routine media used are shown in table $\mathrm{I} . \overrightarrow{\vec{T}}$ New media were used in groups C, D, E, and F; their $\stackrel{\circ}{3}$ composition is shown in table II. The new media were called Victoria media 1, 2, 3, and 4. The reversiono media recommended by Gutman et al (1965) wereused with medium B, and Victoria reversion media? were used with the Victoria media. Group $\mathbf{F}$ rever- $\frac{-}{3}$ sion media were used with medium $G$.

\section{Victoria reversion media}

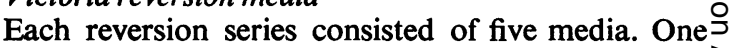
hundred per cent reversion was of the same compo- $\frac{7}{0}$ sition as the blood culture medium on trial, and the rest were of progressively decreasing concentration, $N$ $75 \%, 50 \%, 25 \%$, and $12.5 \%$. The diluent was Oxoid BHI broth. The final step in each reversion series was subculture to Robertson's medium.

\section{SUBCULTURE TECHNIQUE}

After seven days' incubation routine media were sub-尽 cultured to blood agar plates, and the test media ${ }^{+}$ were subcultured to a pour plate. The pour plate $\frac{-}{\circ}$ inoculum was $1 \mathrm{ml}$ of the test medium culture in $9 \mathrm{ml}$ of agar. A pour plate of the same base composition $\frac{\hat{\Phi}}{\mathbb{D}}$ 


\begin{tabular}{llll}
\hline Block & Routine media & & Test media \\
\hline 1 & Brain heart infusion (Oxoid) & Robertson's medium & Nof \\
specimens
\end{tabular}

Table I Test and routine media

\begin{tabular}{|c|c|c|c|c|}
\hline \multirow[t]{2}{*}{ Constituents } & \multicolumn{4}{|c|}{ Quantity $(\mathrm{g} / \mathrm{l})$} \\
\hline & Medium C & Medium D & Medium E & Medium $F$ \\
\hline Sucrose & $200 \cdot 00$ & $200 \cdot 00$ & $200 \cdot 00$ & $300 \cdot 00$ \\
\hline Yeast autolysate & $25 \cdot 00$ & $25 \cdot 00$ & $25 \cdot 00$ & 25.00 \\
\hline $\mathrm{MgSO}_{4} 4 \mathrm{H}_{2} \mathrm{O}$ & $2 \cdot 5$ & 2.5 & $2 \cdot 5$ & $2 \cdot 5$ \\
\hline Agar & $0 \cdot 15$ & 0.15 & $0 \cdot 15$ & $0 \cdot 15$ \\
\hline Heparin & 0.05 & 0.05 & 0.05 & 0.05 \\
\hline Cholesterol & - & 0.02 & 0.02 & 0.02 \\
\hline Thioglycollate & - & - & 1.00 & 1.00 \\
\hline Cysteine & - & - & 1.00 & - \\
\hline Haemin & - & - & 0.04 & 0.04 \\
\hline \multirow{3}{*}{$\begin{array}{l}\text { Brain heart infusion } \\
\text { (Oxoid) } \\
\text { Final pH }\end{array}$} & & & & \\
\hline & 1 litre & 1 litre & 1 litre & 1 litre \\
\hline & $7 \cdot 5$ & $7 \cdot 5$ & $7 \cdot 5$ & $7 \cdot 5$ \\
\hline
\end{tabular}

Table II Composition of new media $(C, D, E$, and $F)$

as the blood culture routine medium was used for groups B, C, D, E, and F, but for group A the medium recommended by Brem (1969) was used, and group $F$ medium was used for group $G$. Group $G$ cultures were in a commercial medium for which there was no recommended subculture method. All subculture plates were incubated for three days before final examination. On the third day agarblockswere subcultured routinely from the pour plates to the appropriate $100 \%$ reversion medium and to Robertson's medium. Cultures which failed to grow in Robertson's medium but which grew in reversion medium were subcultured in a reversion series, reversion media of decreasing concentration being inoculated on successive days.

\section{MICROSCOPIC EXAMINATION}

All pour plates were examined with a stereo microscope (Elvar) using the 2.5 objective lens. In groups $A$ and $B$ agar blocks taken from the pour plates were examined after staining by Dienes' (1939) method using the stereo microscope.

\section{IDENTIFICATION OF CULTURES}

In all cases where an isolate was identified as a bacterial L-form, cultures for vegetative'bacteria were sterile after 14 days' incubation. Cultures were assumed to be in the L-form if typical colonial morphology was seen on plate microscopy and if the principles outlined by McGee et al (1971) were observed, though clinical specimens were not examined microscopically for bacterial L-forms. Vegetative bacteria were identified by standard methods (Cowan, 1974).

OSMOLALITY OF CULTURE MEDIA

This was tested in an MSE model 3D advanced digmatic osmometer with saline standards.

ANTIBIOTIC SENSITIVITY TESTING

Antibiotic sensitivity testing of vegetative bacteria was by the method of Stokes and Waterworth (1972). A similar method was used for L-form sensitivity testing. Pour plates were made and the controls were inoculated on the surface of the medium in the usual way.

\section{Results}

PRELIMINARY WORK

The L-form medium of Gutman et al (1965) was the only medium tested which supported the growth of artificially induced L-form bacteria.

\section{OSMOLALITY OF CULTURE MEDIA}

The osmolality of the routine media is shown in table III, and the osmolality of each L-form medium is shown in table IV.

L-FORM ISOLATION FROM BLOOD CULTURES The results are shown in table IV. Only the Victoria media grew L-form bacteria.

\section{APPEARANCE OF L-FORM COLONIES IN VICTORIA MEDIA}

L-form colonies were easily distinguishable in the Victoria media. The colonies of vegetative bacteria were seen without difficulty on naked-eye inspection of the medium as they gave easily perceptible surface growth. Plate microscopy revealed that such colonies were symmetrical in shape with a smooth surface. Lform colonies were invisible, or only just perceptible on the surface of the agar, and grew in the depths of the medium. Plate microscopy showed that they were irregularly shaped 'mulberry' or 'spider' colonies. 


\begin{tabular}{ll}
\hline Medium & Osmolality (mosm/kg) \\
\hline Brain heart infusion & 398 \\
Robertson's medium & Not tested \\
Cysteine thioglycollate broth & Not tested \\
Difco thiol SPS & 248 \\
Thioglycollate broth & 389 \\
\hline
\end{tabular}

Table III Osmolality of routine culture media

Dienes stain was unreliable in the distinction of vegetative and $\mathrm{L}$-form colonies, since both stained equally well.

Reversion of L-forms to the classical bacterial form was easily accomplished, and in most cases reversion occurred after agar block subculture to Robertson's medium. Only one culture required passage through a full reversion series; this was the yeast isolated from case 2.

\section{ANTIBIOTIC SENSITIVITY TESTING}

The method used was unsatisfactory. It was difficult to obtain a sufficient growth density for testing, and the L-form bacteria had a tendency to revert to the vegetative form unexpectedly.

\section{Discussion}

The L-forms of bacteria were first described by Klieneberger (1935) and named in honour of the Lister Institute where she worked. Since then the nomenclature of cell wall-defective bacteria has become confused. McGee et al (1971) proposed that the wall-defective forms of bacteria should be known as 'wall-defective microbial variants' and tried to define the different types which may be found. They preferred to reserve the term 'L-form' as a description for the 'fried egg' colonial form sometimes seen in cultures of wall-defective bacteria.

In this paper the term L-form means a bacterium which has sustained total or partial cell wall loss. The terminology proposed by McGee and his colleagues was not used, but the cell wall-defective bacteria des- cribed here probably corresponded to the 'trans itional phase variants' of the McGee classificatio $\vec{P}$. The media chosen for testing were three established culture media and four new media called Victor media. The three established culture media were the medium of Brem (1969), chosen because it had been used for the isolation of bacterial L-forms from bloof cultures, the medium of Gutman et al (1965), becaus it gave good results with artificially produced forms, and Difco SPS/sucrose medium, because ot was a commercial culture medium which was said to be suitable for the isolation of $\mathrm{L}$-forms.

It has been realized for some time that certais? factors are of particular importance in the culture of L-form bacteria. Osmotic stabilization is necessary prevent cell lysis, and either sucrose or sodium chloride are used to raise the osmolality of cultures media. It is probable that agar has a supportive effect on the cell wall damaged bacterium. Nimmo and Blazevic (1969) and Dienes (1968) believed that the culture of $\mathbf{L}$-forms was improved in solid or semisolid media, and the success of Rosner (1972) iq improving blood culture isolation rates for vegetative bacteria may be attributable not only to the use sucrose as osmotic stabilizer in the collecting medium but to the use of pour plate cultures. Rosner belieyed that his results were due to an improved recover of vegetative bacteria whose parent strains had sustaing cell wall damage. According to McQuillen (1980 low concentrations of magnesium sulphate exert supportive effect on the $\mathbf{L}$-form cell membrane, bu it is debatable that there is an absolute requiremen for magnesium sulphate, since Nimmo and Blazevic (1969) found that it was not necessary in media cors taining agar. However, magnesium sulphate has been shown to protect the L-form cell against the action lysozyme and complement (Muschel, 1968) and so it use is justifiable for blood culture work.

Cholesterol and yeasts are required by the Mycoplasmas, a group which bears some resem. blance to the bacterial L-forms. The role of choles terol and yeast in L-form metabolism is not known

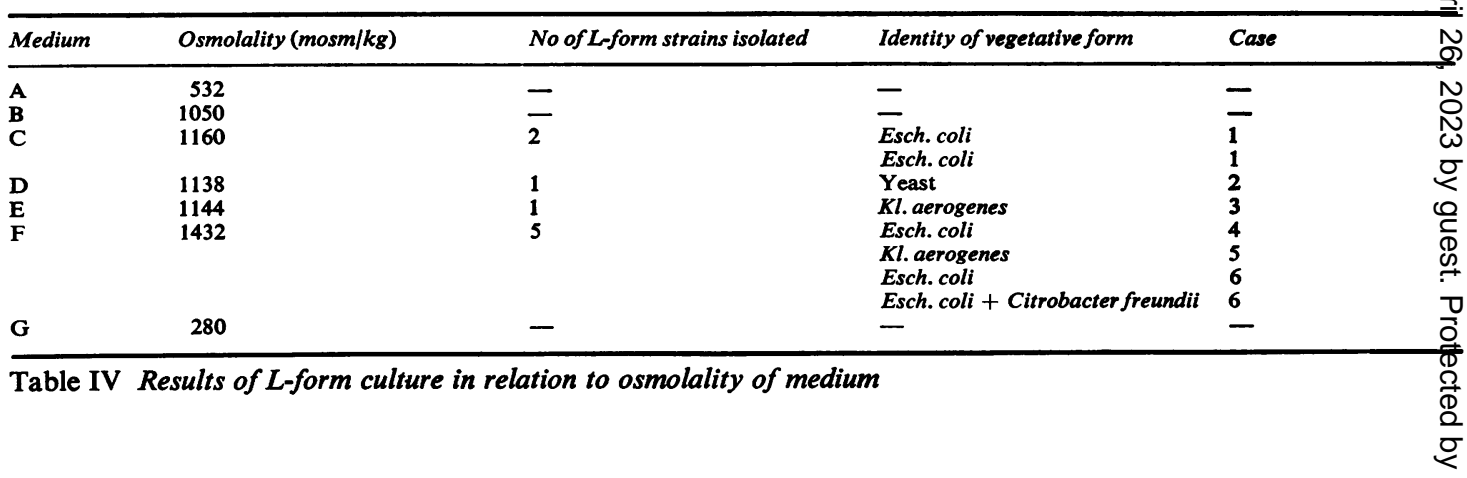


but both were included in the medium of Gutman et al (1965) and in the Victoria media.

The only media which were successful in the culture of $\mathrm{L}$-forms were the Victoria media. These contained all the ingredients listed above, with the exception of Victoria medium 1 (group C) which did not contain cholesterol but which supported the growth of $\mathrm{L}$ form bacteria. Gutman medium (group B) was very similar to the Victoria media in composition but failed to grow L-forms. The only major difference was in the osmolality of the media (table IV). The Victoria media had a higher osmolality than the other media tested, and this suggests that a critical factor in the cultivation of some $\mathrm{L}$-forms is the maintenance of a high osmolality. An osmolality of at least 1100 mosm $/ \mathrm{kg}$ was essential for the recovery of the L-forms of the Enterobacteriaceae in this series, although since the work of Greenwood and O'Grady (1972) indicates that the $\mathbf{L}$-forms of the Enterobacteriaceae may vary in their osmolar requirements, not all Enterobacteriaceae L-forms may require an osmolality of this magnitude. Reports of the isolation of yeast L-forms (Louria et al, 1969; Rosner, 1966) show that a lower osmolality may be adequate for some species, and survival of Haemophilus influenzae protoplasts in conditions of very low osmolality has been demonstrated by Roberts and his colleagues (1974).

Nonetheless it appears that the importance of osmolality in the culture of L-form bacteria has been neglected, and only a few authors (Greenwood and O'Grady, 1972; Roberts et al, 1974) have measured the osmolality of their culture media. It seems possible that the isolation of the L-forms of bacteria will be improved by the use of culture media of very high or of very low osmolality.

My thanks are due to Dr Alistair Glen, of the Department of Biochemistry, Victoria Infirmary, Glasgow, who carried out the measurements of osmolality, and to the technical staff of the Department of Bacteriology, Victoria Infirmary, Glasgow, especially to Mrs Patricia Rowan.

\section{References}

Brem, A. M. (1969). Isolation of L-forms from clinical material. Amer. J. med. Technol., 35, 702-705.

Cowan, S. T. (1974). Cowan and Steels Manual for Identification of Medical Bacteria, 2nd ed. Cambridge University Press, London.

Dienes, L. (1939). L organism of Klieneberger and Streptobacillus moniliformis and other bacteria. J. infect. Dis., 65, 24-42 cited in Medical Microbiology, edited by R. Cruickshank, J. P. Duguid, B. P. Marmion, and R. H. A. Swain. 12th ed., Vol. 2, pp. 525-527, 1975. Churchill Livingstone.

Dienes, L. (1968). Morphology and reproductive processes of bacteria with defective cell wall. Microbial Protoplasts, Spheroplasts and L Forms, edited by L. B. Guze, pp. 74-93. Williams and Wilkins, Baltimore.

Greenwood, D. and O'Grady, F. (1972). The effect of osmolality on the response of Escherichia coli and Proteus mirabilis to penicillins. Brit.J. exp. Path., 53, 457-464.

Gutman, L. T., Turck, M., Petersdorf, R. G., and Wedgwood, R. J. (1965). Significance of bacterial variants in urine of patients with chronic bacteriuria. J. clin. Invest., 44, 19451952.

Klieneberger, E. (1935). The natural occurrence of pleuropneumonia-like organisms in apparent symbiosis with Streptobacillus moniliformis and other bacteria. J. Path. Bact., 40, 93-95.

Louria, D. B., Kaminski, T., Grieco, M., and Singer, J. (1969). Aberrant forms of bacteria and fungi found in blood or cerebrospinal fluid. Arch. intern. Med., 124, 39 48.

McGee, Z. A., Wittler, R. G., Gooder, H., and Charache, P. (1971). Wall-defective microbial variants: terminology and experimental design. J. infect. Dis., 123, 433-438.

McQuillen, K. (1960). Bacterial protoplasts. In The Bacteria, edited by I. C. Gunsalus and R. Y. Stanier. Vol. 1, pp. 249359. Academic Press, New York and London.

Muschel, L. H. (1968). The formation of spheroplasts by immune substances and the reactivity of immune substances against diverse rounded forms. Microbial Protoplasts, Spheroplasts and L Forms, edited by L. B. Guze, pp. 19-29. Williams and Wilkins, Baltimore.

Nimmo, L. N. and Blazevic, D. J. (1969). Selection of media for the isolation of common bacterial L-phase organisms from a clinical specimen. Appl. Microbiol., 18, 535-541.

Roberts, D. E., Ingold, A., Want, S. V., and May, J. R. (1974). Osmotically stable L forms of Haemophilus influenzae and their significance in testing sensivity to penicillins. $J$. clin. Path., 27, 560-564.

Rosner, R. (1966). Isolation of Candida protoplasts from a case of Candida endocarditis. J. Bact., 91, 1320-1326.

Rosner, R. (1972). A quantitative evaluation of three blood culture systems. Amer.J. clin. Path., 57, 220-227.

Stokes, E. J. and Waterworth, P. M. (1972). Antibiotic sensitivity tests by diffusion methods. Association of Clinical Pathologists Broadsheet 55. 